University of Warwick institutional repository: http://go.warwick.ac.uk/wrap This paper is made available online in accordance with publisher policies. Please scroll down to view the document itself. Please refer to the repository record for this item and our policy information available from the repository home page for further information.

To see the final version of this paper please visit the publisher's website. Access to the published version may require a subscription.

Author(s): Ben Rosamond

Article Title: Globalization, the ambivalence of European integration and the possibilities for a post-disciplinary EU studies

Year of publication: 2005

Link to published version:

http://dx.doi.org/10.1080/1351161042000334772

Publisher statement: none 


\title{
Globalisation, the ambivalence of European integration and the possibilities for a post-disciplinary EU studies
}

\author{
Ben Rosamond
}

\begin{abstract}
Using the work of Manuel Castells as a starting point, this article explores the ambivalent relationship between globalisation and European integration and the variety of ways in which the mainstream political science of the EU has attempted to deal with this issue. The analysis here suggests that various 'mainstreaming' disciplinary norms induce types of work that fail to address fully the somewhat paradoxical and counter-intuitive range of possible relationships between globalisation and European integration. The article explores critically four possible analytical ways out of this paradox - abandonment of the concept of globalisation, the development of definition precision in globalisation studies, the reorientation of work to focus on globalisation as discourse and inter and post-disciplinarity. The argument suggests that orthodox discussions of the relationship require a notion of social geography that sits at odds with much of the literature on globalisation and while greater dialogue between disciplines is to be welcomed, a series of profound epistemological questions need to be confronted if studies of the interplay between global and social process are to be liberated from their disciplinary chains.
\end{abstract}

\section{Introduction}

This article offers some reflections on the organisation of academic knowledge about 'globalisation' via a discussion of the relationship between globalisation and European integration within the EU studies literature. ${ }^{1}$ For the purposes of the argument here, the term 'EU studies' corresponds broadly to work on European integration and EU governance within Anglophone political science. As an intervention in a particular wing of a particular field of enquiry, this article may be wholly parochial and that my argument may not apply to other branches of contemporary European studies within the social sciences. However, I suggest that the paper does have a broader application as a thought experiment within the wider field of globalisation studies or, at least, within an increasingly cluttered literature on globalisation that has grown up within the political sciences. 
My argument commences with an observation that I label Castells' paradox. This observes that the relationship between European integration/Europeanisation/EU governance on the one hand and globalisation on the other is puzzling and ambivalent. I then suggest that this ambivalence does not sit well with the modes of enquiry that dominate the mainstream political science of the EU. This 'mainstreaming' within EU studies, itself a product of particular institutional and cultural pressures, induces a form of epistemology that is ill equipped to deal with the problem of globalisation. I then enumerate critically four analytical strategies that could follow from this foundational observation: (a) simple abandonment of the concept of globalisation altogether, (b) the development of definitional precision with regard to the term 'globalisation', (c) a reorientation of globalisation studies to focus on globalisation as discourse and (d) the quest for interdisciplinarity and perhaps 'post-disciplinarity' in EU studies.

The article argues that the relationship between the modes of enquiry found in these mainstream contributions and certain suppositions about social geography are very deep and I question whether orthodox political science epistemologies are capable of encountering conceptions of globalisation that might help us to understand Castells' paradox. I conclude that the issue at stake here is not only a matter of a particular discipline failing to engage with its peers, but also a very deep epistemological conundrum.

\section{Globalisation and European integration: Castells' paradox and the political science of EU studies}

In an oft-cited phrase from the last of his magisterial three-volume The Network Society, Manuel Castells writes that 'European integration is, at the same time a reaction to the process of globalization, and its most advanced expression' (Castells, 2000: 348). At one level this is simple enough to grasp. The European Union (EU) may be read in two ways. The first treats the EU as a collective response among European states to the onset of various transnational economic imperatives. Thus, for example, the EU's member states may have ascertained that the pooling of monetary sovereignty is the most efficacious way to deal with the exigencies of predatory mobile capital. Alternatively, they may invest in European integration as a means to preserve a distinctive model of European political economy. The second sees the EU 
as an agent for the unravelling of (Westphalian) European space, the spread of certain policy orthodoxies across the continent and the emergence of hybrid forms of governance that depart from the models most associated with twentieth century European political economy. But this second approach amounts to treating the EU as an instance of globalisation. The EU - whether conceived as a form of liberal market order or as a hybrid form of multi-level polity - is a realisation of globalisation. In the first part of Castells' paradox globalisation is deemed to be exogenous to European integration and the growth of EU institutional forms and processes. In the second it is fundamentally endogenous. Of course it may be that one element of the paradox precedes the other - although Castells does not elaborate whether this is what he has in mind. Thus, for example, at $\mathrm{T}_{0}$, European states comprehend that globalisation represents some sort of threat or challenge. At $\mathrm{T}_{1}$, they choose collectively to invest in some form of supranationalism by creating, consolidating or delegating additional authority to a set of common institutions. However, by $\mathrm{T}_{2}$, it becomes apparent that the choice to Europeanise in response to globalisation has in fact (either unwittingly or intentionally) resulted in accelerated globalisation, which in turn takes the form of an enlarged liberal market order (where the co-ordinates of public authority have been reorganised) or a polity that represents a functional fit for increased transnationalism. As some authors note, we might also care to pose the question of what occurs at $\mathrm{T}_{0-1}$ (where did globalisation come from?). At this point it is often noted that states themselves are the primary authors of globalisation - for example by liberalising capital control regimes (Milner, 1998). Thus in our example, what occurs at $\mathrm{T}_{0}$ is a rational appreciation the consequence of decisions taken earlier at $\mathrm{T}_{0-1}$ (i.e. governments have seriously compromised their capacity to exercise sovereignty/autonomy in monetary policy). $\mathrm{T}_{1}$ represents an attempt to recapture that monetary sovereignty, albeit collectively (the creation of EMU). However, at $T_{2}$ it becomes clear that this new regime is entirely consistent with the spatial (transnational) and policy (neoliberal) logics of globalisation.

This type of observation is partially, but not entirely, consistent with Ross's observation that 'the unintended consequences of decisions to deepen European integration after 1985 have promoted globalization’ (1998: 179). His analysis deepens Castells' paradox yet further by suggesting that the decisions to create the early post-war experiments in integration may be attributable to national responses to 
something like globalisation (although - significantly - these external economic imperatives were not labelled 'globalisation' at the time), but the key decisions in the EU's history that have resulted in it eventually sponsoring globalisation (the creation of the single market programme in the mid-1980s), were caused

less by globalization than by strategic choices to accelerate integration than to continue ... discrete national strategies. These choices were constructed around path-dependent constraints left by the earlier period of European integration before globalization was in current vocabulary (Ross, 1998: 179).

This sounds a bit like Wallace's oft quoted claim that

European integration can... be seen as a distinct west European effort to contain the consequences of globalization. Rather than be forced to choose between the national polity for developing policies and the relative anarchy of the globe, west Europeans invented a form of regional governance with polity-like features to extend the state and harden the boundary between themselves and the rest of the world (Wallace, 1996: 17).

This idea is reinforced by Wallace's later observation that the EU represents the latest attempt by Europeans to manage the peculiarly high levels of transnational exchange that have been ever-present in the European region since antiquity (Wallace, 2000a). The key difference resides in Ross's casual observation that at the foundation of modern European integration what we now label 'globalisation' did not go by that name. This raises the question of whether globalisation can be globalisation if it is not understood to be globalisation.

The complexity of Castells' paradox is revealed by analysing the pronouncements of policy actors who offer rhetorical announcements about the relationship between globalisation and the EU. This is not the place for a detailed review of policy discourse (for which see Hay and Rosamond, 2002; Rosamond, 1999; 2002; forthcoming), but the following claims have all been registered in recent years among European-level policy actors:

- Europe is challenged by globalisation (which is represented by world-wide economic liberalisation). The appropriate response is to Europeanise policy capacities to ensure the delivery of neo-liberal policy solutions both internally via devices such as competition policy, and EMU and externally through proactive 
support for and investment in the global multilateral free trade order (see especially Brittan, 1998).

- The 'European social model' is threatened by globalisation, which is forcing societies to converge around an American style model of capitalism characterised by radical deregulation, labour market flexibility and welfare retrenchment. The only way for member-states to preserve the cherished 'European social model' is to invest further in the EU (Diamantopolou, 2002).

- EMU is one way in which Europe is being globalised.

- EMU is the way in which Europeans have sought to reclaim control over monetary policy in the face of globalisation.

- The European model of integration represents a successful and exportable attempt to engage in the governance of globalisation (Prodi, 2000)

- The EU should be active in promoting the social dimension of globalisation by becoming an active global campaigner for core labour standards and corporate social responsibility (Commission of the European Communities, 2001a; 2001b)

- The EU has a responsibility to help 'set globalisation within a moral framework' (European Council 2001)

- The EU is one among 'les acteurs de la globalisation’ (Lamy, 2000).

- The European Commission should be empowered to negotiate on the EU's behalf with regard to all matters relating to globalisation (Lamy and Ferry, 2002).

- The new globalised order should be advanced through the leadership of a 'G8' style collection of regional organisations, of which the EU would be one (Verhofstadt, 2001)

- The EU is a prop of an anti-democratic globalised world order that operates in the interests of an elite minority (George, 2001)

Perhaps the fact that there is no clear picture of the relationship between globalisation and European integration should not surprise us. Indeed, as Kelstrup (2001) observes, this ambivalence is inscribed into the very conditions of the EU's foundation by virtue of the fact that both neo-liberal and liberal/social democratic impulses fed into its creation. In other words the EU should be understood as a natural arena for competing conceptions of globalisation. The possible existence of multiple subject positions visà-vis globalisation within EU policy circles is illustrated in the table below with a 
very simple attempt to plot putative roles for the EU that follow logically from three stylised normative views of globalisation. The roles ascribed to the EU in each case have both internal and external manifestations: respectively the purpose of EU governance in light of globalisation and the proper projection of the EU into world politics.

Table 1: Possible relationships between globalisation and the European Union

\begin{tabular}{|l|l|l|}
\hline \multirow{2}{*}{$\begin{array}{l}\text { NORMATIVE } \\
\text { VIEW OF }\end{array}$} & \multicolumn{2}{|c|}{ ROLE ASCRIBED TO THE EUROPEAN UNION } \\
\cline { 2 - 3 } & \multicolumn{1}{|c|}{ INTERNAL } & \multicolumn{1}{c|}{ EXTERNAL } \\
\hline 1. POSITIVE & $\begin{array}{l}\text { Promotion of deregulation } \\
\text { and liberalisation in European } \\
\text { states }\end{array}$ & $\begin{array}{l}\text { Promotion of liberalised } \\
\text { world order in line with the } \\
\text { precepts of global institutions }\end{array}$ \\
\hline 2. AMBIVALENT & $\begin{array}{l}\text { Filtering of the benefits of } \\
\text { liberalisation, while } \\
\text { preserving the distinctive } \\
\text { qualities of European } \\
\text { capitalism }\end{array}$ & $\begin{array}{l}\text { Promotion of humanised } \\
\text { version of globalisation } \\
\text { and/or the social dimension of } \\
\text { globalisation }\end{array}$ \\
\hline 3. NEGATIVE & $\begin{array}{l}\text { Resistance to } \\
\text { Americanising/liberalising } \\
\text { processes. Preservation of the } \\
\text { virtues of the European model } \\
\text { of society }\end{array}$ & $\begin{array}{l}\text { Promotion of an alternative } \\
\text { model of world order }\end{array}$ \\
\hline
\end{tabular}

Source: Rosamond (forthcoming): chapter 1, table 1.1.

Much of the foregoing is suggestive of the value of a particular analytical strategy for studying the relationship between globalisation and European integration that is largely consistent with the treatment of globalisation as discourse (see below and Rosamond, 1999; 2001; forthcoming). However, such an approach is not typical of the attempts to evaluate the globalisation-EU relationship in within EU studies. I want to suggest that while this invocation - following Castells' paradox' - of a simultaneous countervailing logic at the interstices between globalisation and European integration makes intuitive, empirical and (moreover) analytical sense, a certain mode of social scientific reasoning disallows such a conclusion, or at the very least finds it deeply problematic. Rather Castells' passing comment ought, from this stance, to be treated at best as a zero-sum hypothesis to be tested following thorough investigation of the evidence. Thus either (a) the EU is an agent of globalisation or (b) 
the EU is a response to globalisation. We might, of course, discover elements of truth in both propositions. Perhaps some elements of the EU's activity induce globalisation, while others resist it. At first sight, the student of European integration is presented with a promising candidate independent variable ('globalisation') that perhaps explains recent moves toward an integrated European economy or maybe offers clarification on why the institutions of European governance have taken their particular form. Yet, at the same time, Castells suggests that the dependent variable ('European integration') is bound up in intimate ways with the processes that might actually explain it. Indeed, the effect of our attempt above to offer a temporal narrative of how the paradox could be sustained was ultimately to dissolve the independent variable into the dependent variable so that they become one and the same thing.

The extant work, perhaps in anticipation of this epistemological dog's breakfast, tries hard to retain separation between globalisation and European integration. This strategy is reinforced with a very clear understanding that the variables under scrutiny operate within discrete spatial domains (usually the global, the regional/European and the national/domestic). This is heuristically necessary because of the social science at play in these contributions is interested primarily with hypothesising the existence of linear patterns of causation. From the vantage point of this stance, therefore, the analytical separation of globalisation as a variable necessarily brings with it separation of spatial scales because the question/hypothesis demands this to be so. Four (somewhat stylised) examples of this kind of work are laid out here to illustrate the point.

- One common narrative, as we have seen, is to propose that European integration is the way in which states have chosen to react when confronted with the imperatives of globalisation. Thus research is designed to test the proposition that imperatives emanating from the global begin to have national/domestic effects which induce states to construct institutions of governance as an intermediate level (the European).

- Another research programme is concerned with the extent to which the EU acts effectively as an intervening variable between the global and the national/domestic (see Verdier and Breen, 2001). This allows for a degree of 
differentiation: are, for example, capital and labour markets in European countries protected by the EU from the vicissitudes of globalisation? (Answer: no). Have European electorates de-aligned in the way anticipated by some advocates of the globalisation hypothesis? (Answer: no - see also Garrett, 1999). This approach requires a degree of mathematical manipulation (and thus quantification) of variables so to establish plausible differentiation between 'realities' and counterfactual situations where the intervening variable of the EU is absent. Obtaining significant results then allows a degree of working back from the evidence in order to conclude whether (in line with the first approach above) 'Europeanisation' can be construed as a form of collective insurance against globalisation - a way in which states actively choose to have 'less globalisation'.

- A third take on EU-globalisation from within this orthodoxy is interested in how the domestic effects of globalisation might spill over into the conduct of governance at the European level (Hennis, 2001). Thus the primary causal relationship under scrutiny is the consequences of globalisation for the practice of pluralist politics within European countries. Globalisation is held to cause alterations in both governmental preferences and the patterns of domestic interest group activity. In policy domains where interest intermediation is heavily Europeanised (such as agriculture), there will be automatic further disruptive effects to patterns of policy-making at the EU level.

- Finally, institutionalist scholars (notably Schmidt, 2003) have been interested in how domestic institutions mediate external stimuli and pressures. In such work both globalisation and Europeanisation are read as external inputs into national polities. Left unchecked, these processes, emerging from alternate spatial levels of action, would transform (i.e. 'globalise' or 'Europeanise') domestic political economies. However, institutional forms at the domestic level are hypothesised as mediators/refractors/prisms that either preserve existing modus operandi or (more probably) lend a particularly national character to the transformations occasioned by external inputs.

In short, a good deal of the political science of EU-globalisation concerns itself with all manner of hypothetical relationships between globalisation, European integration/Europeanisation/the EU and national/domestic societies. In this respect, EU studies - as it always has been - displays commendable loyalty to its primary 
parent discipline in general and the mainstream sub-disciplines of international and comparative political economy in particular. The intention here is not to dismiss this work out of hand. Rather, I intend to show how such work falls into a number of awkward traps that lie in the path of much political science work on globalisation.

Immediate objections to the type of work described above are relatively easy to identify. For convenience, they may be summarised quickly as follows:

- Is this work really about globalisation? To what extent is use of the term 'globalisation' in such studies merely a modish conceptual accessory. Might alternative, more precise - and thus more measurable - terminology be appropriate. Can, for example, the variable 'globalisation' really be reduced to ‘increased volumes of cross-border trade’? (Fligstein and Merand, 2002). Would it not be better and more precise social science to talk about the latter rather than the former?

- It follows that different contributors operate with alternate understandings of globalisation. Therefore, there is a potential problem with the compatibility of results that are obtained. This is a common complaint about globalisation studies: that the term contains massive elasticity and is use as sloppily by academics as it is by policy practitioners.

- Insofar as globalisation is properly defined and specified within these contributions, the term is used in a narrow and largely economistic manner. In most work of the type described here, globalisation is either a process or a condition that affects or emanates from the domain of the economy. As any reading of he voluminous literature from - inter alia - sociology, cultural studies, geography and anthropology will confirm, globalisation can be defined much more broadly and is properly regarded as a multidimensional process. The concentration of political science studies of globalisation upon the economic manifestations of globalisation has numerous consequences. Aside from offering an unnecessarily narrow take on the significance of globalisation for European integration, such work simply reproduces established policy 'common sense' about globalisation that is similarly blinkered. If policy-makers offer a one dimensional depiction of globalisation, then academic studies should be open to adopting a more critical posture (Rumford and Murray, 2003: 87) 
- The continued emphasis on a world of tiered spatial scales of human action infringes much of what is innovative and distinctive about the cutting edge work on globalisation. As Scholte notes, affirming an alternate definition of globalisation from that normally proffered in political economy literature: '[i]t is helpful, analytically, to distinguish different spheres of social space; however, concretely the global is not a domain unto itself, separate from the regional, the national, the provincial, and the household' (Scholte, 2002: 27). The conceptions of globalisation within the work described above rely on a very old-fashioned notion of geography, where 'globalisation' becomes a synonym for transactions across borders and the rise of interdependence. In other words, what is being studied here is not globalisation, but internationalisation (Scholte, 2002: 8-10).

Scholte compares the reifying errors of those who separate the global from other spatial domains to the long-standing heuristic mistake of International Relations of hardening the boundaries between domestic and foreign and inside and outside (2002: 28). The question this begs is why has this tendency to reify been reproduced? I have remarked already upon the main rationalist epistemological tendencies in the political science of EU studies. With these tendencies come particular norms about how explanations should be conducted and thus what kind of work is deemed to be 'good' political science (an emphasis on explanation as the discovery of causality, the need to clearly separate and specify candidate variables and so on). My point is that these pathologies are integral to the practice of disciplinary (and some might say disciplining) political science. Within EU studies there is an increasingly voluble narrative about the urgent need to make the field more 'rigorous' and thus a better reflection of the mainstream of political science (Rosamond, 2004 for a detailed argument). With cheerful Whiggishness, EU studies past is variously chastised as being (a) a rather sleepy branch of International Relations (and thus simultaneously obsessed with 'integration' and impervious to the value of asking key questions from comparative political science about the EU political system), (b) nothing more than 'area studies' (and thus empiricist and lacking any explanatory power) and (c) characterised by sloppy scholarship and 'bad' social science. This process of disciplinary 'mainstreaming' might be read an the incipient 'Americanisation' of EU studies in that its most vocal practitioners preach the virtues of the likes of rational choice political science for EU studies. Rational choice institutionalism has even been 
confirmed by one author as the new 'normal science' of EU politics (Dowding, 2000). The most frequently perceived danger of disciplinary mainstreaming is that it normalises (in a Kuhnian sense) scholarship and disciplines or at least devalues deviant work. What is lost, argue critics of various persuasions, is the capacity or more precisely the acceptability of practising research (in the sense of borrowing insights or engaging in reflection) across the disciplinary divide) (Manners, 2003; Wallace, 2000b).

If we bring the argument back specifically to globalisation and European integration, it becomes apparent that there is a relationship between the narrow focus of work in the area (within the political science of EU studies) and a series of pressing norms that exert themselves within the discourse of the dominant parent discipline. This implies that less restrictive, more insightful and more open work on the globalisationEuropean integration relationship - work perhaps that is capable of comprehending Castells' paradox - could follow from the loosening of the strictures associated with disciplinary mainstreaming (Rumford and Murray, 2003).

\section{Four analytical strategies}

This may be so, but it does not follow that a move to an inter/multi/trans/postdisciplinary future is the only way to grapple with the problems that emerge from scrutinising the work within the EU studies mainstream on globalisation and European integration. At the risk of some simplification, I list four broad analytical strategies that could be adopted in response to some of the objections raised above. It should be said that not all of these are consistent with bringing EU studies into protracted dialogue with the complex globalisation literature.

\section{(a) Abandonment of the concept of globalisation}

The first response involves abandoning the project of globalisation studies as hopelessly flawed (and thus curtailing enquiry into the relationship between globalisation and European integration). It has three variants. The first variant relies on proof that (i) globalisation is not - in fact - happening or (ii) that many of the causal effects frequently attributed to globalisation are false. Note that these positions are somewhat distinct. Argument (i) follows from work that refutes the central claims of the 'globalisation hypothesis', amounting - in effect - to the idea that globalisation 
is a myth best characterised as either academic hyperbole or rhetorical exaggeration. Argument (ii) - itself a sub-species of some of the work outlined earlier in this paper - is perfectly consistent with the idea that globalisation is 'out there'. In this latter case, institutions (broadly defined) are deemed to be capable of refracting, intercepting or blocking globalisation in ways that preserve pre-existing national practices and patterns of politics and policy-making. In both cases, 'globalisation' is criticised for being a distinctly unhelpful concept. In the first, it represents a misdescription of the structural environment within which public authorities operate. In the second, globalisation is construed as a descriptor for the effects of a set of largely external forces. Thus, if the effects are not discernible, then globalisation itself as a category becomes compromised.

Abandonment does not represent the end point of this analytical strategy. The proof of either theorem serves the function of providing rigorous disconfirmation of the claims of assorted policy actors, journalists and corporate actors. In this view, actors may be premature in their description of the world they inhabit, but they may also be shown to be using a sloppy term strategically as a way of justifying particular courses of action (say a particular cocktail of neo-liberal, anti-welfarist and fiscally recidivist policies). The (national) state is capable of sustaining its role as a robust interlocutor between domestic societies and the globe and it need not shed its historic redistributive functions. Nor should it transform itself into a competition state, cast a as latter day Hayekian regulatory 'night watchman', whose sole raison d'etre is the supply of a rule bound order for market exchange. Domestic corporate taxation regimes need not be characterised by an unseemly 'race to the bottom' for fear of (mobile) capital exercising the exit option. Labour markets need not be flexibilised to the point where the institutional props of social democracy are sacrificed.

Much of the foregoing can be found in abundant recent research in comparative and international political economy. While few explicitly place 'globalisation' on the ejector seat and press the red button, the prognosis for the concept of globalisation as a useful social scientific term is extremely bleak.

Applied to the EU, this sub-type of political economy tells a potentially interesting set of stories. First, the EU is not a case of globalisation - either economically or in institutional form. Rather the EU exists as the institutional prop of a regionalised (as 
opposed to globalised) economy, an analytical distinction that is crucial in Hirst and Thompson's debunking of the globalisation myth (Hirst and Thompson, 1999) and in much subsequent work that endeavours to show that globalisation is not happening.. Second, the reason that EU may exhibit such characteristics is the fact that it acts effectively as a method, chosen collectively by states, as a new means to insulate themselves from the pressures of the global economy. In its most extreme form, such an argument would be consistent with the principal-agent approach in political science that reads institutions (such as formal supranational bodies like the European Commission and the European Court of Justice) as the product of acts of deliberate delegation by national governments (Pollack, 2003), selected because of their supposed capacity to perform governance tasks more efficiently.

This is, as intimated above, the abandonment, not of 'globalisation' in its analytic totality, but of a particular conception of globalisation. Broadly speaking, this is a conception of globalisation that is eschewed because it is proved useless within the norms of the mainstream discourse of political science. But at the same time is a conception that has been rendered comprehensible within that discourse. Thus, its rejection is somewhat inevitable.

The second variant of the abandonment strategy follows from the perception that 'globalisation' is a concept without explanatory power. It lacks analytical power because it is characterised by tremendous elasticity. It is used in multiple ways by multiple authors and more precise, delineated terminology should be adopted to describe processes that originate at the global level and impact upon domestic societies, perhaps persuading policy-makers to invest in forms of collective insurance such as the EU. In short, we can explain these phenomena quite sufficiently without polluting our analysis with the decidedly unhelpful term 'globalisation'. Curiously this particular move is not always made. In O’Rourke’s enlightening discussion of the historical interplay between Europe and the wider global economy since the eighteenth century, we are reminded that in terms of (a) commodity market integration (b) capital market integration/foreign direct investment and (b) labour mobility/migration, the $19^{\text {th }}$ century demonstrated greater integration than the late $20^{\text {th }}$ (O’Rourke, 2002). Yet, throughout his work, O’Rourke slips happily between the 
terms 'globalisation' and 'economic integration' - to the extent that the reader can only assume that he means them to be precise synonyms.

The third strategy of abandonment recognises the qualitative distinctiveness of globalisation as transcendence of fixed territorial spatial scales yet, to some extent, buys into the scepticism that either this state of affairs is coming to pass or that the key societal dynamics of the present world order are actually inducing such a radical shift in human interaction. Hence Zürn's preference for the term 'societal denationalisation' (Zürn, 2002). Here there is an expectation that this 'denationalisation', represented by a radical rise in cross border transaction of various kinds (not just economic transactions), induces a loosening of the bond between national states and their corresponding societies. However, this does not necessarily loosen the 'placeboundedness' (Zürn, 2002: 101) of social relations - something that a distinctive theory of globalisation would predict. European integration, then, can be read as an instance of societal denationalisation that is accompanied by (a) a shift in the mode of governance from traditional hierarchical notions of government to new regulatory forms of organisation and control, not necessarily monopolised by formal public authorities and (b) a transfer of these functions to new post-national agencies of governance (the EU). But European integration is nevertheless, as its name suggests, 'placebounded', constituting as it does a reorganisation of governance within a bounded territorial geography.

(b) Definitional precision: normal science or the differentiation of globalisation studies

A second response emerges from the observation that the concept of globalisation is poorly defined. But rather than pursuing the strategy of abandonment, this position strives for an agreed and fastidious definition of globalisation. A strategy for definitional precision has two alternate strands, one recidivist in that it would be highly supportive of the disciplinary mainstreaming described above; the other perhaps less so. The first variant would reiterate the point about the concept's present elasticity and the consequences for its analytical utility. From this orthodox standpoint, the only way to rescue the explanatory capacity of a concept such as globalisation - short of abandoning it - is to secure a consensus on the meaning of the concept and proceed thereafter in the manner of a Kuhnian 'normal science'. In 
practice this might mean developing a set of commonly agreed proxy indicators for globalisation, which can then be deployed as an independent variable in multiple studies of the causal chains that occur within and between distinct levels of human action and tiers of governance. While such a move would conform to the tenets of 'mainstreamed' political science, there has been no obvious attempt to do this.

That said, there are several examples of attempts to develop ongoing indices of globalisation that hold implications for the study of Europe. Chief among these is the annual globalisation index (now in its fourth year) published in Foreign Policy magazine in conjunction with A.T. Kearney (Foreign Policy 2001, 2002, 2003, 2004a). The index is produced by a weighted and normalised calculation that organises data on 14 variables into 4 'baskets': economic integration, cross border human contact, availability and use of internet technology and engagement in world politics. This produces a country by country ranking of globalisation. We are told that 'Europe is the most global region' (Foreign Policy, 2004b), an impression reinforced by noting that of the $13 \mathrm{EU}$ states that are measured, five (Ireland [ranked 1], Netherlands [4], Finland [5], Austria [9] and Denmark [10]) are all in the top ten. Ten are in the top twenty and all are in the top 30 (Foreign Policy, 2004). Academic engagement with the index has concentrated on the its construction and the appropriate weighting to be assigned to its component variables (see especially Lockwood, 2001), rather than on the fundamental epistemological problems that lie at the heart of the enterprise (though see Rosamond, 2003; Scholte, 2002). Most obviously, the index leaves territorial integrity intact. Countries are globalised and some are more globalised than others. What this really means, and thus what this index really measures, are the extent to which countries are exposed to external economic inputs, the extent to which they engage with other countries, the degree to which people move in and out of each country and the extent to which they are connected to elsewhere through communications technology. The index is meaningless if globalisation is defined differently, as either the fundamental transcendence of territory or even the reorganisation of territory, because the bordered territorial space of the nation-state is completely privileged. It commits the folly identified by Scholte (2000) - of methodological territorialism. 
Another way this might be accomplished would involve acceptance of the claim consistent with (a) above - that the term 'globalisation' obscures more than it clarifies. This line of reasoning implies that the social scientist should disaggregate the catch-all term 'globalisation' into its component (measurable) parts in order to quantify the impact of, say, commodity market integration, capital market integration or human/labour migration. Either way, the creation of a normal science of globalisation or its components allows study of the relationship between global and European integration to (re)conform to the well known social scientific virtues such as parsimony, clear hypothesis formulation, the transparent operationalisation of variables and the achievement of potential replicability in research (King, Keohane and Verba, 1994).

The second possible move under this heading is most clearly advocated in the work of Scholte (2000; 2002). Here the idea is to concede the point that in many cases, the use of the term globalisation is misplaced and to agree that useful knowledge about social processes can be attained via the deployment by alternative, more precise concepts. The trick is to utilise a definition of globalisation that adds value, not least since work that investigates the term often rejects the importance of globalisation because it is working with an inappropriate understanding of the concept. Thus globalisation needs to be identified as those processes that engineer discontinuities in the character of social geography and induce - in certain fields of human life, but by no means all - a shift towards supraterritorial relations.

An alternative here, in direct contrast to the approach advocated by Scholte, is the idea that globalisation (as manifested in ventures such as the EU) is actually a process of re-territorialisation (Brenner, 1999). The point made by writers like Brenner is important to emphasise. There is a fundamental acceptance that globalisation studies is properly focussed on the 'accelerated circulation of people, commodities, capital, money, identities and images through global space' (Brenner, 1999: 431), but that it also has to take account of two further things. The first is the continued existence of 'fixed and immobile territorial organisation' (Brenner, 1999: 432), while the second is the idea that globalisation (defined as neo-liberal globalisation) is bound up with 'major transformations of territorial organisation on multiple geographical scales' (Brenner, 1999: 432). In other words - and reinforcing the ideas that follow from 
Zürn's notion of 'denationalisation' - the reassignment of governance functions in Europe that finds expression in the 50-year drift towards the supranationalisation of policy competence is a form of this territorial rescaling. Moreover, this should be read as a fundamental feature of globalisation. Castells' paradox reappears in alternative vocabulary.

To return to Scholte's comments, it is perhaps important to reflect upon the social scientific implications of the type of move he advocates. First of all, the quest for a clear, qualitatively distinct conception of globalisation is not a monistic move. It disqualifies neither other attempts to do the same nor the continued existence of work that emphasises territorial boundedness. It offers a gentle suggestion to those who write about globalisation that perhaps they are not using a particularly helpful concept for their purposes. He also notes - rightly - that '[s]tudents of politics have conventionally regarded governance as a territorial question, that is, as a matter of local and national government with the latter sometimes meeting in "international" (again code for inter-territorial) organisations' (2002: 23). Furthermore, as noted above, he suggests that political science (in the form of International Relations particularly) has reified boundaries between distinct spheres/levels of human action (2002: 27). So there are two underlying norms that contribute to the particular way in which EU-globalisation has been encountered in the political science of EU studies: a preoccupation with territoriality and an associated tendency to describe social space in terms of discrete domains.

It is worth probing a little deeper. 'Territorialist method', Scholte argues, 'means formulating concepts and questions, constructing hypotheses, gathering and interpreting evidence, and drawing conclusions in a spatial framework that is wholly territorial. These intellectual habits are so engrained that most social researchers reproduce them more or less unconsciously' (2002: 23). The question of where to place emphasis in this sentence is vital. Is the distinctive thing about territorialist method the deployment of a territorial framework, or does everything else (from 'formulating' to 'conclusions') also follow from territorialist foundations? If the latter is so, then the move beyond methodological territorialism is really quite profound. As suggested earlier, the mainstream spatial framework of territorialism is heuristically useful for social scientists of a particular (indeed dominant) persuasion because it 
allows for the construction of propositions based upon hypothesised relationship between those spatial/territorial scales. The conventional methodologies of political science fit remarkably well with this basic axiom. It follows that if we seek to move beyond territorialist method, then the habits of conventional social science are called into question. This may help to account for the reason why the mainstream has been largely resistant to conceptions of globalisation that logically dissolve these heuristic devices and thereby render them unworkable. If reification of boundaries and levels is indeed an error of political science/international studies (Scholte, 2000: 27-28), then perhaps the error is pathological. It is not just a concept (globalisation) that is at stake here, but an entire epistemology.

\section{(c) Globalisation as discourse}

The third analytical strategy in some ways rescues the idea of globalisation for European studies by avoiding the numerous elephant traps presented under (a) and (b) above. But it can also be reached by engaging with the other two strategies outlined here and showing what they miss. The headline claim of such an approach is that globalisation studies need to take the discursive dimensions of globalisation much more seriously. This move can be justified in a number of ways.

Despite the heroic accumulation of evidence that refutes, challenges, qualifies or complexifies elements of the 'globalisation hypothesis', actors in the policy world continue to use the term freely and unrigorously. Policy/corporate/journalistic communities do not only deploy the term, they justify particular courses of action by invoking the idea of the imperatives of globalisation (Hay and Rosamond, 2002; Hay and Watson, 2003). This might provoke us to think about the incapacity of social science to penetrate policy consciousness or to disabuse the political class of its strategic preconceptions, but it also suggests an urgent need to look at the way in which 'globalisation' is used in public debate. How, for example, does globalisation as a concept fit into pre-existing patterns of political discourse (Rosamond, 2002)? To what extent does 'globalisation' constitute a discursive frame or commonly held worldview, from which particular programmatic ideas follow? Has globalisation, for example, displaced the Cold War as the predominant discursive rationale for the existence of the EU (Delanty, 1998)? To what extent are ideas about globalisation embedded in the minds of policy actors? Or are they simply deployed strategically as 
ways of justifying policy choices on the basis of non-negotiable external pressures? To what extent do organisations - such as the European Commission - develop within themselves conflicting or rival narratives about globalisation?

From this vantage point, 'globalisation' is perhaps best construed as a theory about the world, held by actors who inhabit that world. Moreover, and importantly, globalisation is a future-oriented theory in that it describes - by dissolving complex, overlapping and probably contradictory processes and events into a single signifier that is readily understood (Cameron and Palan, 2004). Within such discursive practice, it is not necessary to define globalisation. It has a remarkable intersubjective quality. It is possibly best characterised as an 'empty signifier'. Its content is fluid in that different actors are calling to attention a bundle of referents when they invoke 'globalisation', but the basket of referents (if indeed there are any) may be variable from actor to actor. It is empty also in that 'globalisation' possesses no necessary normative content. Actors may react to globalisation based upon positive, negative or confused and ambivalent orientations towards it. Various normative orientations may signal diverse positioning strategies in relation to globalisation (see again table 1 above).

Following from this first rationale (which directs analysts to study ideas and the production/transmission/exchange of knowledge about globalisation) follows a second, which tries to think about the relationship between ideas and material effects. To what extent does the recurrent presence of 'globalisation' in public discourse have 'truth effects'? Does the constant invocation of globalisation by policy actors have the effect of allowing them to 'sing into existence' (Smith 2003) a world in the very image of that discourse? Thus even if globalisation at $\mathrm{T}_{0}$ is demonstrable nonsense, might actions taken by actors who assume globalisation to be real bring about globalisation at $\mathrm{T}_{1}$ in the future? Causal effects that are imagined have material effects that ultimately realise those causal processes (see Starie, 1999: 41). Good examples include debates about globalisation and tax competition in advanced industrial (especially European) societies. The 'hyperglobalisation' hypothesis (as discussed in Held et al, 1999) assumes that high levels of inward investment in an age of globalisation (transnational production and perfectly mobile capital) are a function of low corporate tax regimes. Should governments fail to attend to this basic rule, then 
capital will exercise its right to exit and seek more favourable fiscal regimes elsewhere. A supposed effect of globalisation, and thus a feature of a globalised economy, is a race to the bottom as governments rationally court mobile investors with low corporate taxation regimes. Governments In other words behave like competition states should. It matters not that there is deep econometric scepticism about the alleged relationship between capital mobility and domestic taxation regimes. The fact that governments believe the globalisation hypothesis to be true (or at least act as if they do) means that the effective globalised world they imagine (a world of minimum corporate taxation) comes into existence (Hay and Rosamond, 2002). We can run the same thought experiment through the current obsession in Europe with flexible labour markets (Hay, 2002) or through the supposed causes of welfare retrenchment in advanced industrial democracies (Hay, 2001) and yield similar results. In each case a set of policy patterns consistent with predictions of a particular variant of globalisation theory come into existence, and they are justified by policy actors with reference to causal patterns that are, to say the least, deeply suspect (or at least judged so by social scientists).

The study of globalisation as discourse has been hitherto cast as a project capable of investigating critically the forms of knowledge held by and the discursive strategies practised by policy actors, with particularly fruitful applications in the study of contemporary European transformations. But the scope of such work could and should be broadened to think through the interplay of these discourses, their material effects and the role of academic discourses of globalisation. We might then be persuaded that the capture of a particular conception of globalisation by a particular set of social scientific disciplines (and here business studies and economics might join political science in the dock) has the capacity to help 'sing into existence' a world where rapacious currency trading is the norm, where governments excuse themselves from their redistributive responsibilities and where there is no alternative. This is not to suggest that academics are directly responsible for any of the pernicious effects usually ascribed to globalisation. Indeed, as we have seen, much of the political science of EU-globalisation is deeply sceptical (normatively as well as analytically) about the various 'truths' said to be integral to globalisation. We might even argue that such political science discourse has the signal virtue of talking directly to the policy 'common sense' of globalisation. Finding effective communicative conduits 
between academic analysis and policy discourse would be the obvious strategy to follow.

But this would be premature and the reason is outlined very well by Cameron and Palan, (2004: 4-5) who insist that 'we can only understand the role of theory, belief, narrative and so on, as integral parts of the production of social reality itself'. Cameron and Palan build a case for the intensive study of 'communal story telling' about globalisation. Their central point here is that the act of naming something 'globalisation' is a social act of objectification that constitutes the starting-point for all manner of narrative spinning around the named object. Clearly this is of central importance to the study of the policy world and it is also important to recognise, as Cameron and Palan do (2004: 9), that the purpose and methodology of communal story telling about globalisation differs between academic and policy discourses. Each has different rules for theorising the world, but the point is that academic practice is as much in the business of attributing meaning and producing stories about globalisation as its policy world counterpart. The fact that the rules of narrative in social scientific and policy discourse are different may account better for the alleged incapacity of the former to disabuse the latter of its myths. The rules that help to generate political science's knowledge about globalisation are rationalistic, objectivisitic and rooted in an almost Newtonian obsession with elementary patterns of causation. Those that inform policy discourses are future oriented to the extent that the objectification of globalisation allows for 'preparation for an anticipated future' (Cameron and Palan, 2004: 10) rather than the development of a theory of the present. Yet it seems to have been the function of political scientists (of various sorts) and economists to give these future orientations meaning by apprehending (and thus [re]naming) these future oriented concepts and, therefore, objectivising them yet further by applying orthodox social scientific techniques to their investigation.

\section{(d) Inter- or post-disciplinarity in EU studies}

The final analytical strategy is simply stated. The cul-de-sacs of EU-globalisation studies demand a disciplinary reorientation. The problem with the extant work, put crudely, is that EU studies has been too narrowly focussed in its encounters with globalisation. Scholars have failed conspicuously to engage with work on globalisation in cognate disciplines (Robertson and Haque Khondker, 1998). The 
opening up of EU studies to the wider social sciences will reveal a blooming secret garden of work that will remove narrow rationalistic or economistic obsessions from the literature on EU-globalisation (Rumford and Murray, 2003). Interdisciplinarity promises escape from restrictive and narrow domains of knowledge production. Rumford and Murray (2003) recommend greater disciplinary promiscuity in EU studies as a necessary step to disengage the field from its historic predisposition to think about the EU as a teleological instance of integration This pathological obsession begets multiple problems: globalisation is equated with deep integration, transnational space is an aggregate of national space and as a consequence broader conceptions of globalisation that (a) go beyond the economic and (b) carry with them more profound notions of transcendent social space are ruled out of court. Thus the story EU studies (that is broadly the dominant political scientific variant of EU studies) fails to tell is of 'how globalization increases disjunctures between society, economy and state and in doing so de-totalizes existing polities’ (2003: 90). The solution is a multidisciplinary a 'consortium of diversity' to guide EU studies away from its central obsession, which provokes focus on certain assumptions about space and causal patterns between domains of human action, and thereby away from its chronic incapacity to recognise the inherent value of globalisation literature in all of its rich diversity.

The idea that EU studies has a pathological inability to ask important questions is taken up by Manners (2003), who makes a similar appeal for EU studies to open itself to wider tendencies in not only the social, but also the natural sciences. He provides an account of why this dialogue is missing that chimes with some of my comments above (see also Rosamond, 2004). He too is concerned about the effects of disciplinary mainstreaming and the consequent tendency to normalise (in the Kuhnian sense) the study of the EU. In EU studies, we may have reached a point where Fuller's maxim applies: 'disciplinarity should be treated as a necessary evil of knowledge production - the more necessary it is made to appear, the more evil it becomes' (2003: 1). The choices made by political scientists of the EU are not innocent; they are framed by a series of factors that influence epistemological choices. In conditions where there are strenuous pressures for disciplinary mainstreaming, then what counts as acceptable knowledge production (in terms of both output and method) comes under closer scrutiny. The pressures that have been inserted into EU studies 
reflect the preferences of the rationalist mainstream in US political science. Combined with a constellation of sociology of knowledge factors - tenure decisions, editorial policies of existing and new journals and so on - these preferences become powerful beacons of what constitutes good/admissible social science. What has come under particular pressure, especially in the United States, is the most obvious inter/multidisciplinary lifeboat for EU studies: the organisation of enquiry into area studies institutes and professional associations (see Rosamond, 2004). Thus calls for greater interdisciplinarity have, first of all, to engage with these conditions of knowledge production. Particular audiences within EU studies (the profesionalised/Americanised/rationalist mainstream) will regard the argument as $a$ priori bogus (that is if they even chose to pick up the journal in which it has been published!).

\section{Conclusions}

The relationship between globalisation and European integration is puzzling. Policy discourse suggests an ambivalent relationship at best and this ambivalence is recorded neatly in Castells' paradox. The overwhelming instinct of political scientists who have explored EU-globalisation to date has been to perform enquiry within an established set of disciplinary rules, which, on the face of it, prohibit the acceptance of Castells' paradox as either a starting point or a conclusion. There is, in other words, a predisposition to 'test' for globalisation via one or a permutation of (a) measuring the extent to which individual national economies in Europe are globalised, (b) engaging in comparative historical analysis to explore the proposition that we are living through a special or intensive period of globalisation, (c) examining the intervening impact of European institutions upon the reception of globalisation in domestic political economies. This is an instinct, moreover, that strives for the establishment of a firm understanding of the nature of globalisation as a variable (preferably exogenous and therefore treatable as an unproblematic independent variable/explanans).

Assuming - as good disciplinary cosmopolitans - that this state of affairs is problematic, it is possible to discern a series of analytical strategies to escape from the series of contradictions and cul-de-sacs that afflict the political science of EUglobalisation. Some of these involve retaining the logic of a mainstreamed political 
science, while others potentially find alternative takes on the puzzle at hand and thereby avoid the quagmire of more conventional work.

So there is an intimate relationship between the normal type of political science of EU-globalisation and a series of prior epistemological commitments that (a) reinforce an Alamo-like retention of discrete spatial levels of action that in turn reveal assumptions about particular non-transcendent form of (territorial) social geography and (b) regard as useful knowledge that which specifies identifiable patterns pf causation. Thus the problem is not simply confined to disciplinary mainstreaming and the consequent failure to absorb insights from across disciplinary divides. Rather the problem falls squarely into the realm of epistemology and it at this level that critique should be developed as part of a project to expose the apparent poverty of a (still emergent) social science of the EU that replaces a tradition of speculation about Europe (Manners. 2003: 68) with rigid disciplinary orthodoxies. These orthodoxies are pernicious in so far as they are disciplining and take disciplinary consolidation well beyond its obvious rationale of protecting scholars from external interference (Fuller, 2003). They are problematic because of the ways in which they produce knowledge in ways that presume a social geography that is profoundly territorial. This methodological territorialism is required in order to practice a certain type of political science. Such work can happily dismiss the idea of globalisation, but it cannot admit a notion of globalisation that offers (threatens) a transformative understanding of this geography.

\section{Notes}

1. Research informing this paper was funded by the UK Economic and Social research Council’s ‘One Europe or Several?’ programme (award L213 252 024).

\section{References}

Brenner, N. (1999) 'Globalisation as Reterritorialisation: The Re-scaling of Urban Governance in the European Union’, Urban Studies, Vol. 36 No. 3, pp.431-451.

Brittan, L. (1998) Globalization versus Sovereignty: the European Response (Cambridge: Cambridge University Press).

Cameron, A and Palan, R. (2004) The Imagined Economies of Globalization, London: Sage.

Castells, M. (2000) End of Millennium, second edition, Oxford: Blackwell. 
Commission of the European Communities (2001a) Promoting Core Labour Standards and Improving Social Governance in the Context of Globalisation, Communication from the Commission to the Council, the European Parliament and the Economic and Social Committee, Brussels 18.7.2001, COM(2001) 416 final. http://europa.eu.int/comm/trade/pdf/comcls_en.pdf

Commission of the European Communities (2001b) Promoting a European Framework for Corporate Social Responsibility - Green Paper COM(2001) 366 final

http://europa.eu.int/comm/employment_social/soc-dial/csr/greenpaper_en.pdf

Delanty, G. (1998) 'Social Theory and European Transformation: Is there a European Society?', Sociological Research Online, Vol. 3 No. 1, http://www.socresonline.org.uk/3/1/1.html

Diamantopolou, Anna (2002) 'European Integration and Governance: Challenges and Opportunities', address to the Institute of European Studies, University of Montreal, 25 April

http://europa.eu.int/comm/dgs/employment_social/speeches/250402ad.pdf

Dowding, K. (2000) 'Institutionalist Research on the European Union', European Union Politics, Vol. 1 No. 1, pp.125-144.

European Council (2001) Annex 1: 'Laeken Declaration on the Future of the European Union', Presidency Conclusions, Laeken Meeting of the European Council, 14-15 December. Press Release: Laeken - Brussels (14/12/2001) Nr: 00300/1/01

http://ue.eu.int/Newsroom/related.asp?max=1\&bid=76\&grp=4061\&lang=1

Fligstein, N. and Merand, F. (2002) 'Globalization or Europeanization? Evidence on the European Economy Since 1980’, Acta Sociologica Vol. 45 No.1, pp.7-22.

Foreign Policy (2001) ‘Measuring Globalization’, Foreign Policy Jan/Feb (2001) http://www.foreignpolicy.com/issue_janfeb_2001/atkearney.html

Foreign Policy (2002) ‘Globalization’s Last Hurrah?’ Foreign Policy Jan/Feb (2002)

Foreign Policy (2003) 'Measuring Globalization: Who’s Up, Who’s Down?', Foreign Policy Jan/Feb, pp.60-72.

Foreign Policy (2004a) 'Measuring Globalization: Economic Reversals, Forward Momentum, Foreign Policy, Jan/Feb http://www.foreignpolicy.com/story/cms.php?story_id=2493

Foreign Policy (2004b) 'Measuring Globalization: Economic Reversals, Forward Momentum', http://www.foreignpolicy.com/story/cms.php?story_id=2493\&page=11\#1 
Fuller, S. (2003) 'Interdisciplinarity. The Loss of a heroic Vision in the Marketplace of Ideas’, Interdisciplines No. 3, http://www.interdisciplines.org/interdisciplinarity/papers/3

Garrett, G. (1999) Partisan Politics in the Global Economy, Cambridge: Cambridge University Press.

George, S. (2001) 'Response to the Open Letter of the Prime Minister of Belgium Guy Verhofstadt’, 30 October, http://nni.org/george/misc/response.htm

Hay, C. (2003) 'What's globalisation got to do with it?', inaugural lecture, Department of Political Science and International Studies, University of Birmingham, 20 March,

http://www.bham.ac.uk/POLSIS/department/staff/publications/hay_inaugural.htm

Hay, C. and Rosamond, B. (2002) 'Globalization, European Integration and the Discursive Construction of Economic Imperatives’, Journal of European Public Policy Vol. 9 No. 2, pp. 147-167.

Hay, C. and Watson, M. (2003)`The Discourse of Globalisation and the Logic of No Alternative: Rendering the Contingent Necessary in the Political Economy of New Labour', Policy and Politics, Vol. 30 No. 4, pp.

Held, D., McGrew, A., Thompson, Goldblatt, D. and Perraton, J. (1999) Global Transformations: Politics, Economics and Culture, Cambridge: Polity

Hennis, M. (2001) 'Europeanization and Globalization: The Missing Link', Journal of Common Market Studies, Vol. 39 No. 5, pp. 829-850.

Hirst, P. and Thompson, G. (1999) Globalization in Question, $2^{\text {nd }}$ ed. (Cambridge: Polity Press)

Kelstrup, M. (2001) 'The European Union and Globalisation: reflections on strategies of individual states’, COPRI Working Paper 38, , Copenhagen Peace Research Institute http://www.copri.dk/publications/WP/WP\%202001/38-2001.doc

King, G. Keohane, R.O and Verba, S. (1994) Designing Social Inquiry: Scientific Inference in Qualitative Research, Princeton, NJ: Princeton University Press.

Lamy, P. (2000) ‘Europe and Globalisation’, Speech at Sorbonne University, Paris, 16 June http://europa.eu.int/comm/trade/speeches_articles/spla26_en.htm

Lamy, P. and Ferry, J.P (2002). The Europe We Want, London: Arch Press/The Policy Network, 2002.

Lockwood, B (2001) How Robust is the Foreign Policy/Kearney Index of Globalisation?, CSGR Working Paper, University of Warwick, No. 79/01 http://www.warwick.ac.uk/fac/soc/CSGR/wpapers/wp7901.pdf 
Manners, I. (2003) 'Europaian Studies', Journal of Contemporary European Studies Vol. 11 No. 1, pp.67-83.

Milner, H.V. (1998) 'Regional economic co-operation, global markets and domestic politics: a comparison of NAFTA and the Maastricht Treaty', in Coleman, W.D. and Underhill, G.R.D. (eds) Regionalism and Global Economic Integration: Europe, Asia and the Americas, London: Routledge, pp. 19-41.

O’Rouke, K.H. (2002) 'Europe and the Causes of Globalization, 1790-2000', in Kierzkowski, H. (ed.) Europe and Globalization, Basingstoke: Palgrave Macmillan, pp.64-86.

Pollack, M.A. (2003) The Engines of European Integration: Delegation, Agency and Agenda Setting in the EU, Oxford and New York: Oxford University Press.

Prodi, R. (2000) 'Europe and Global Governance', speech to the $2^{\text {nd }}$ COMECE Congress, Brussels, 31 March.

http://europa.eu.int/comm/external_relations/news/03_00/speech_00_15.htm

Robertson, R. and Haque Khondker, H. (1998) 'Discourses of Globalization:

Preliminary Considerations’, International Sociology Vol. 13 No. 1, pp. 25-40.

Rosamond, B. (1999) Globalization and the Social Construction of European Identities’, Journal of European Public Policy Vol. 6 No. 4, pp. 652-668.

Rosamond, B. (2001) ‘Constructing Globalization’, in Fierke, K.M. and Jørgensen, K.E. (eds) Constructing International Relations: the Next Generation, New York: M.E. Sharp, pp. 201-219.

Rosamond, B (2002) 'Imagining the European Economy” "Competitiveness" and the Social Construction of "Europe” as an Economic Space', New Political Economy Vol. 7 No. 2, pp. 157-177.

Rosamond, B. (2003) 'Babylon and On: Globalization and International Political Economy’, Review of International Political Economy, Vol. 10 No. 4, pp. 661-671.

Rosamond, B. (2004) '(European) Integration Theory, EU Studies, Disciplinary History and the Sociology of Knowledge', University of Warwick, mimeo.

Rosamond, B. (forthcoming) Globalization and the European Union, Basingstoke and New York: Palgrave Macmillan.

Rosenberg, J. (2000) The Follies of Globalization Theory, London; Verso

Ross, G. (1998) ‘European Integration and Globalization’, in Axtmann, R. (ed.)

Globalization and Europe: Theoretical and Empirical Investigations, London: Pinter, pp. 164-183.

Rumford, C. and Murray, P. (2002) 'Globalization and the Limitations of European Integration Studies: Interdisciplinary Considerations’, Journal of Contemporary European Studies, Vol. 11 No. 1, pp.85-93. 
Schmidt, V.A. (2002) The Futures of European Capitalism, Oxford: Oxford University Press.

Scholte, J.A. (2000) Globalization: A Critical Introduction, Basingstoke and New York: Palgrave Macmillan.

Scholte, J.A. (2002) 'What is Globalisation? the Definitional Issue - Again', CSGR Working Paper, University of Warwick No. 109/02 http://www.warwick.ac.uk/fac/soc/CSGR/wpapers/wp10902.pdf

Smith, S (2003) 'Singing Our World into Existence: International Relations Theory and September 11', Presidential Address, International Studies Association, Portland, OR http://www.ex.ac.uk/shipss/news/VCinaug.htm (forthcoming in International Studies Quarterly, July 2004)

Starie, P. (1999) 'Globalisation, the State and European Economic Integration', Journal of European Area Studies, Vol. 7, No. 1, pp 39-53

Verdier, D. and Breen, R. (2001) 'Europeanization and Globalization: Politics Against Markets in the European Union’, Comparative Political Studies Vol. 34 No. 3, pp.227-262

Verhofstadt, G. (2001) 'Open Letter: The Paradoxes of Anti-Globalisation', http://premier.fgov.be/tpoics/press/e_press23.html .

Wallace, H. (1996) 'Politics and Policy in the EU: the Challenge of Governance', in Wallace, H. and Wallace, W. (eds) Policy-Making in the European Union, $3^{\text {rd }}$ ed., oxford: Oxford University Press.

Wallace, H. (2000a) 'Europeanisation and globalisation: complementary or contradictory trends’, New Political Economy Vol. 5 No.3, pp. 369-382.

Wallace, H. (2000b) 'Studying Contemporary Europe', British Journal of Politics and International Relations, Vol. 2 No. 1, pp.95-113. 